\title{
UPORABA DIGITALNEGA MODELA VIŠIN IN SATELITSKEGA POSNETKA RapidEye ZA ZAZNAVANJE KRAŠKIH KOTANJ IN BREZSTROPIH JAM PODGORSKEGA KRASA
}

\author{
Aleš Grlj, mag. geogr.*, dr. Dejan Grigillo** \\ * Trpčane 22, SI-6250 llirska Bistrica \\ ** Oddelek za geodezijo, Fakulteta za gradbeništvo in geodezijo Univerze v Ljubljani, \\ Jamova cesta 2, SI- I000 Ljubljana \\ e-mail: alesinar.grlj@gmail.com, dejan.grigillo@fgg.uni-lj.si \\ Pregledni znanstveni članek \\ COBISS 1.02 \\ DOI: 10.4312/dela.42.7.129-147
}

\section{Izvleček}

Speleogeneza je proces nastajanja, razvoja in izginjanja jam. Zaključni stadij razvoja jame imenujemo brezstropa jama. Proučevanje le-teh nam lahko pomaga pri razumevanju krasa in kraških pojavov. Ker so brezstrope jame bodisi kotanje na površju ali le zaplate nekraških sedimentov z bujnejšim rastjem, v članku preučujemo možnosti kabinetnega prepoznavanja teh pojavov na podlagi njihovih morfometričnih lastnosti in spektralnih lastnosti vegetacije, ki jih prerašča. Raziskava je osredotočena na širše območje Podgorskega krasa v jugozahodni Sloveniji.

Ključne besede: kras, brezstropa jama, kraška kotanja, NDVI, geomorfometrija, DMV, samodejno prepoznavanje oblike

\section{USE OF DIGITAL ELEVATION MODEL AND RapidEye SATELLITE IMAGE TO LOCATE KARST DEPRESSIONS AND UNROOFED CAVES OF PODGORSKI KRAS}

\begin{abstract}
Speleogenesis is the process of formation, development and disappearance of caves. The final stage in a cave development is called unroofed cave. The study of those features can help us understand karst landscape and karst phenomena. Since the unroofed caves are depressions on karst surface or just patches of non-karstic sediments with more vigorous vegetation, the study examines the possibility of their identification on the basis of morphometric characteristics and spectral properties of vegetation cover. The study is focused on a wider area of the Podgorski kras in southwestern Slovenia.
\end{abstract}

Key words: karst, unroofed cave, karst depression, NDVI, geomorphometry, DEM, automated feature recognition 


\section{UVOD}

Brezstrope jame so bile kot kraške oblike prepoznane razmeroma pozno. Kljub nekaterim starejšim objavam, ki se nanašajo na oblike jam v zaključnih fazah speleogeneze (Dawkins, 1874; cv: Mais, 1999; Kraus, 1894; cv: Mais, 1999), lahko velik delež pri proučevanju in uveljavitvi pojma $\mathrm{v}$ strokovni javnosti pripišemo slovenskim raziskovalcem. Ti so, predvsem v obdobju izgradnje slovenskih avtocest, pojav opisovali, analizirali ter umestili v krasoslovno in geomorfološko znanost (Knez, Šebela, 1994; Mihevc, 1996; Šušteršič, 1998; Geršl, Stepišnik, Šušteršič, 1999; Knez, Slabe, 1999; Mihevc, 2007; Stepišnik in sod., 2009; Brus, 2012).

Brezstrope jame so končni stadij speleogeneze oziroma razvoja jame. Kraška ali kemična denudacija, v manjši meri tudi udiranje stropa, je jamam popolnoma odstranila strop (Mihevc, 2001). Čeprav se lahko pri oblikovanju brezstropih jam strop delno tudi zruši, jih moramo jasno ločiti od udornic, kjer je rušenje prevladujoč proces (Mihevc, 2001; Stepišnik, 2006; Stepišnik, 2010; Gabrovšek, Stepišnik, 2011; Stepišnik, 2011). Kako se je brezstropa jama odprla na površje, nam kažejo ostanki podornih skal in ostrorobega grušča (Mihevc, 2001). Podorne skale med sedimentom ali vidnejši ostanki stropa kažejo na zrušitev stropa v končni fazi odpiranja jame. Zapolnjene jame se korozijsko spremenijo $\mathrm{v}$ brezstrope jame, delno ali nezapolnjene jame pa se v brezstropo jamo spremenijo s počasnim ali hitrim udorom stropa, pojavljanjem oken ali s premikanjem vhoda, če je ta odprt (Mihevc, 2001).

Običajno prepoznamo brezstrope jame kot podolgovate, jarkom podobne plitve kotanje na površju. V njih najdemo avtogene jamske sedimente (sigo) ter alogene sedimente (ilovico, nekarbonatne prodnike ...), ki jih je vodni tok prinesel v jamo, ko je bila ta še hidrološko aktivna (Mihevc, 2001).

Oblika brezstropih jam ali njihovih odsekov je odvisna tako od oblike in tipa nastanka jamskih rovov kot reliefnih značilnosti površja, kjer se nahajajo (Brus, 2012). Pri jamskih rovih freatičnega nastanka, kjer so rovi navadno v vzdolžnem prerezu poševni, in vodoravnem zniževanju površja, se brezstropa jama pojavlja kot niz vrtačam podobnih kotanj. Podobno se kažejo ostanki vertikalnih jamskih odsekov in ostanki jam vadozne cone. Za nastanek izrazito podolgovatih brezstropih jam na ravnem površju morajo biti rovi, iz katerih so nastale, epifreatično preoblikovani oziroma izravnani v epifreatični coni s procesi kot so parageneza, vrezovanje in nastanek obhodnega rova. Freatični rovi se lahko pojavljajo tudi kot izrazito podolgovate brezstrope jame, kadar se rov odpre v pobočju, vzporednem z njim. Ni pa nujno, da bo tak rov izražen kot kotanja v pobočju. Zaradi površinskega izpiranja sedimenta takšno brezstropo jamo zaznamo bolj kot nekakšen plitev uleknjen erozijski jarek ali zaplato fluvialnega sedimenta. V nasprotnem primeru, kadar se rov odpre v pobočju, ki poteka bolj ali manj pravokotno na smer rova, bo brezstropa jama veliko manj razpotegnjena uleknina $v$ pobočju. Zaradi površinskega spiranja bo navzdol po pobočju razpotegnjena le sled sedimenta (Knez, Slabe, 2007).

Medtem ko večina literature o brezstropih jamah opisuje ta pojav na slovenskem krasu, smo o zaznavanju kraških kotanj v slovenski literaturi našli zgolj dve objavi: tematiko je v diplomskem delu obravnaval Obu (2011) in jo kasneje objavil še v članku (Obu, 
Podobnikar, 2013). Sicer se je z razvijanjem metod za samodejno prepoznavanje reliefnih oblik ukvarjalo več avtorjev, med njimi Krevs (1992) ter Podobnikar in Možina (2008). Pri delu Obuja (2011) gre za popolnoma avtomatiziran postopek zaznavanja kotanj na podlagi digitalnega modela višin (DMV). Algoritem je napisan za program ArcMap 9.3.1 ter je razdeljen v štiri korake: računanje porečij, omejevanje kotanj, omejevanje kotanj višjega reda in izločanje nekraških kotanj. Drugi del algoritma razdeli zaznane kotanje v različne razrede po morfometričnih značilnostih na vrtače, udornice, kraška polja idr.

Nabor tuje literature s področja avtomatiziranega zaznavanja kraških kotanj je nekoliko večji. Rahimi in Alexander (2013) sta primerjala rezultate različnih metod kartiranja in zaznavanja vrtač v Minnesoti. V programu MATLAB sta razvila algoritem, ki v treh korakih samodejno prepozna vrtače, ter rezultate primerjala $\mathrm{z}$ drugimi pristopi k rešitvi problema.

Podobno kot prejšnja raziskava, tudi prispevek Doctorja in Younga (2013) primerja več načinov zaznavanja kraških kotanj. Prvi način je ročno kartiranje kotanj na podlagah, izdelanih iz DMV: osenčenost reliefa (angl. Hillshade), osenčenost naklonov (angl. Slopeshade), indeks topografskega položaja (angl. Topographic Position Index) ter na letalskih posnetkih. Drugi način temelji na obdelavi DMV, od zapolnjevanja kotanj, odštevanja hidrološko pravilnega modela reliefa od originalnega modela do končne vektorizacije kotanj.

Nekoliko drugačen pristop k samodejnemu zaznavanju kraških kotanj sta razvila Fuyuan in Yunan (2013). Njun način temelji na prepoznavanju petih običajnih površinskih kraških pojavov na podlagi sklenjenih plastnic: osamljenih hribov, osamljenih vrtač, gruč hribov, gruč vrtač ter gruč hribov z vrtačami.

Med iskanjem literature smo našli samo en primer raziskave s področja samodejnega oziroma polsamodejnega zaznavanja kraških kotanj, ki vključuje tako analizo modela reliefa kot analizo satelitskih posnetkov. Guimarães in sod. (2005) so pri obdelavi modela reliefa uporabili isto metodo kot Doctor in Young (2013), iz satelitskega posnetka pa so izračunali normirani diferencialni vegetacijski indeks (NDVI).

Iskanje brezstropih jam smo izvedli s podobno obdelavo DMV, ki jo kot drugi način opisujeta Doctor in Young (2013), vendar smo postopek nadgradili, da lahko z njim zaznamo tudi kotanje, ki se nahajajo znotraj večjih kotanj. Pri tem smo razvili pristop iterativnega zapolnjevanja kotanj z naraščajočimi višinskimi omejitvami zapolnjevanja. $\mathrm{Z}$ razvito metodo pridemo do popolnejših podatkov o kotanjah. Postopek smo dopolnili z rezultati klasifikacije pokritosti tal. V tem delu smo se v večji meri naslonili na Oštirjevo knjigo Daljinsko zaznavanje (2006) ter diplomsko delo Urške Kanjir z naslovom Objektna klasifikacija rabe tal iz podatkov daljinskega zaznavanja (2009).

\section{OBRAVNAVANO OBMOČJE IN UPORABLJENI PROSTORSKI PODATKI}

Metodo iskanja kraških kotanj in brezstropih jam smo preizkusili na širšem območju Podgorskega krasa v jugozahodnem delu Slovenije. Gams (2004) imenuje to območje Socerbsko-Podgorski kras, vendar le nižji uravnan del. Višje ležeči del, ki se začne z zahodnim pobočjem hriba Kojnik (802 m n. v.) ter nadaljuje proti jugovzhodu in državni 
meji z Republiko Hrvaško, pripada Čičariji. Obravnavano območje smo na severu omejili z mejo med Republiko Slovenijo in Republiko Italijo, na jugu z mejo z Republiko Hrvaško, zahodni rob območja poteka po strmi stopnji na prehodu med nizko dinarsko planoto in flišnim delom Slovenske Istre. Meja se na vzhodnem delu vleče po vznožju Slavniškega pogorja in kontaktu z nekarbonatnimi kamninami v dnu doline potoka Griža. Reliefno se območje deli na nižji in uravnan severni del ter bolj razčlenjen in vzpet južni del. Obravnavano območje ima površino $52,63 \mathrm{~km}^{2}$ (slika 1).

Slika 1: Obravnavano območje

Figure 1: Study area

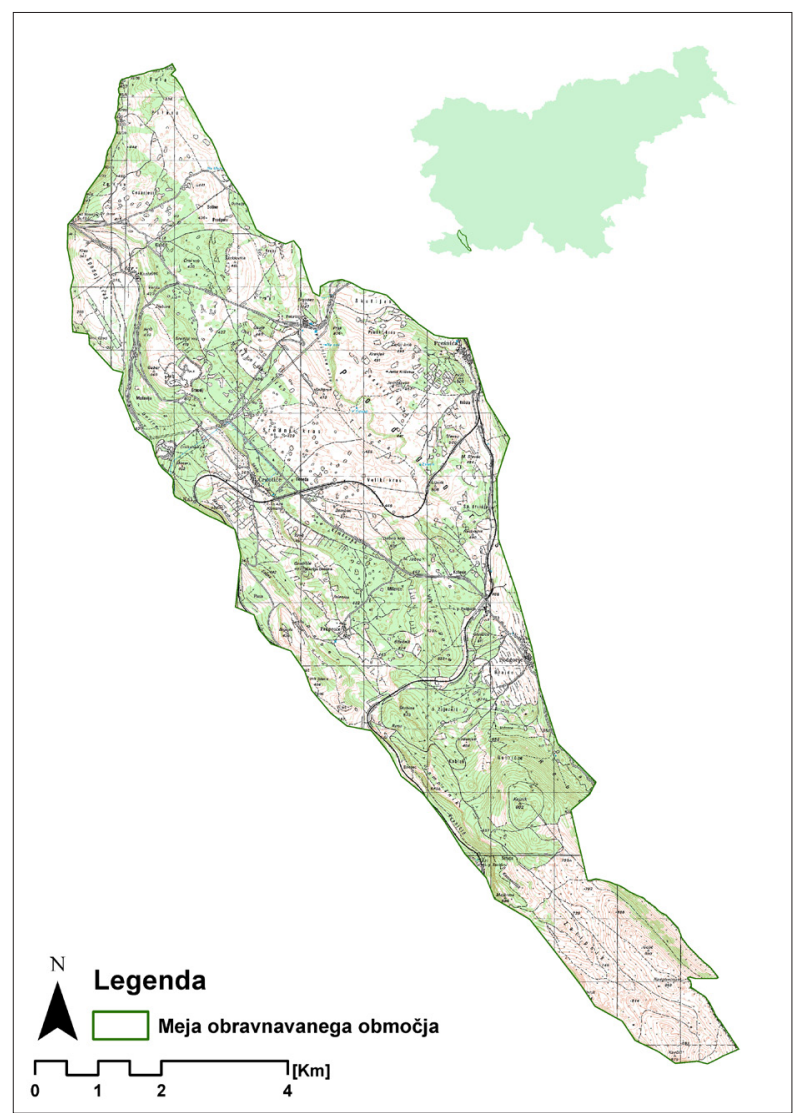

Vir/Source: GURS, DTK 25, 1999

Območje sekajo štirje glavni narivni prelomi (palmanovski, socerbski, kastelski in petrinjski). Ob njih najdemo večje ali manjše luske klastičnih sedimentov - laporja eocenske starosti. Ostalo površje gradijo različni apnenci ter apnene breče in grušč na strmejših pobočjih (Digitalna Osnovna geološka karta, list Trst, 2003). 
Na obravnavanem območju prevladujejo različne oblike rendzin in rjave pokarbonatne prsti. Manjše zaplate prsti predstavljajo še distrične ter evtrične rjave prsti, ki sovpadajo z luskami nekarbonatnih kamnin, ter hipoglej in litosol (Pedološka karta 1 : 25.000, 2008).

Največji delež obravnavanega območja je poraščen z gozdovi (54,1\%). Od tega predstavlja grmičasti gozd 23,5 \%, 13,7 \% iglasti gozd, 6,8 \% listnati gozd in 10,1\% mešani gozd. Kmetijske površine $\mathrm{z}$ drobnoposestniško strukturo obsegajo 4,5 \% površine, pretežno kmetijske površine $z$ večjimi območji vegetacije pa $0,1 \%$. S travniki in pašniki je pokritih 40,5 \% površine območja, preostali delež $(0,7 \%)$ predstavljajo gole površine oziroma kamnolomi (Corine Landcover, 2006). Grmičasti in listnati gozd se najpogosteje pojavljata kot submediteranski toploljubni gozdovi črnega gabra in puhastega hrasta $(O s$ tryo-Quercetum pubescentis), iglasti gozd pa je zastopan z gozdovi črnega bora (Pinus nigra). Na travniških in pašniških površinah je najbolj razširjena združba nizkega šaša in skalnega glavinca (Carici humilis-Centaureetum rupestris) (Kaligarič, 1997).

V raziskavi smo za zaznavanje kotanj uporabili državni digitalni model višin s stranico celice oziroma prostorsko ločljivostjo $5 \mathrm{~m}$ (DMV 5). DMV 5 je bil izdelan leta 2007 s prevzorčenjem DMV v ločljivosti 12,5 m ter fotogrametrično obdelavo (Podobnikar, 2008). Delno posodobljen je bil v letih 2009-2011 v okviru cikličnega aerosnemanja Slovenije (CAS) kot podlaga za izdelavo ortofota. Natančnost modela je na odprtih območjih ocenjena na $1 \mathrm{~m}$ in na zaraščenem terenu $3 \mathrm{~m}$ (GURS, 2014).

Za izdelavo maske pozidanih oziroma antropogeno preoblikovanih površin, s katero smo izločali kotanje, ki so posledica človekovega delovanja v prostoru, smo uporabili satelitski posnetek RapidEye, posnet 18. 8. 2012. Posnetek smo obdelali na Centru odličnosti VesoljeSI, njegova prostorska ločljivost v nadirju je 6,5 m (RapidEye Satellite Sensor, 2013).

\section{METODOLOGIJA}

Raziskava je sestavljena iz treh metodoloških sklopov. V prvem delu smo zaznavali kraške kotanje iz DMV na podlagi iterativnega zapolnjevanja kotanj. Drugi del predstavlja klasifikacija satelitskega posnetka za izdelavo karte pokritosti tal in izločitev antropogeno preoblikovanih površin. Z izračunom NDVI za vsak tip pokritosti tal smo v tem sklopu določili območja bujnejše vegetacije (višja vrednost NDVI), ki odražajo večjo verjetnost pojavljanja alogenih sedimentov in s tem nakazujejo na brezstrope jame. $\mathrm{V}$ tretjem sklopu smo glede na morfometrične lastnosti kotanj in prostorskih odnosov med njimi določili, katere od zaznanih kotanj so brezstrope jame. Raziskava je bila zasnovana tako, da smo rezultate prvih dveh metodoloških sklopov združili in jih skupaj analizirali v zadnjem sklopu.

V raziskavi smo uporabili podatke, ki so opisani v poglavju 2, obdelava pa je potekala s programsko opremo Arc Map 10.1, Idrisi Selva 17.0 ter IDLE. Z uporabo slednjega sta bila za prvi in tretji metodološki sklop izdelana skripta v programskem jeziku Python 2.7.2, ki omogočata samodejno izvedbo vseh korakov obdelave podatkov pripadajočih sklopov. Skripta uporabljata orodja, ki jih za prostorske analize ponuja program ArcMap 10.1. Obdelava podatkov v drugem metodološkem sklopu je potekala deloma v programu Idrisi Selva 17.0, deloma v programu ArcMap 10.1. 


\section{I. Zaznavanje kotanj iz DMV}

Celoten postopek se izvaja samodejno preko skripta, napisanega $\mathrm{v}$ ta namen. Postopek lahko na kratko podamo kot zaporedje ukazov programa ArcMap 10.1 (Fill, Raster Minus, Reclassify, Raster To Polygon, Delete Field), ki jih kličemo iz Arcpy-modula. Skript torej najprej zapolni kotanje vhodnega DMV, od zapolnjenega DMV odšteje vhodni DMV, vrednosti rezultata odštevanja pa reklasificira na 1 , kjer je zaznana kotanja, in 0 , kjer so bile $\mathrm{v}$ rezultatu odštevanja vrednosti 0 , torej ni kotanj. Reklasificirane kotanje pretvori v vektorski sloj poligonov (slika 2).

Slika 2: Pojmovni model zaznavanja kotanj

Figure 2: Conceptual model of depression recognition

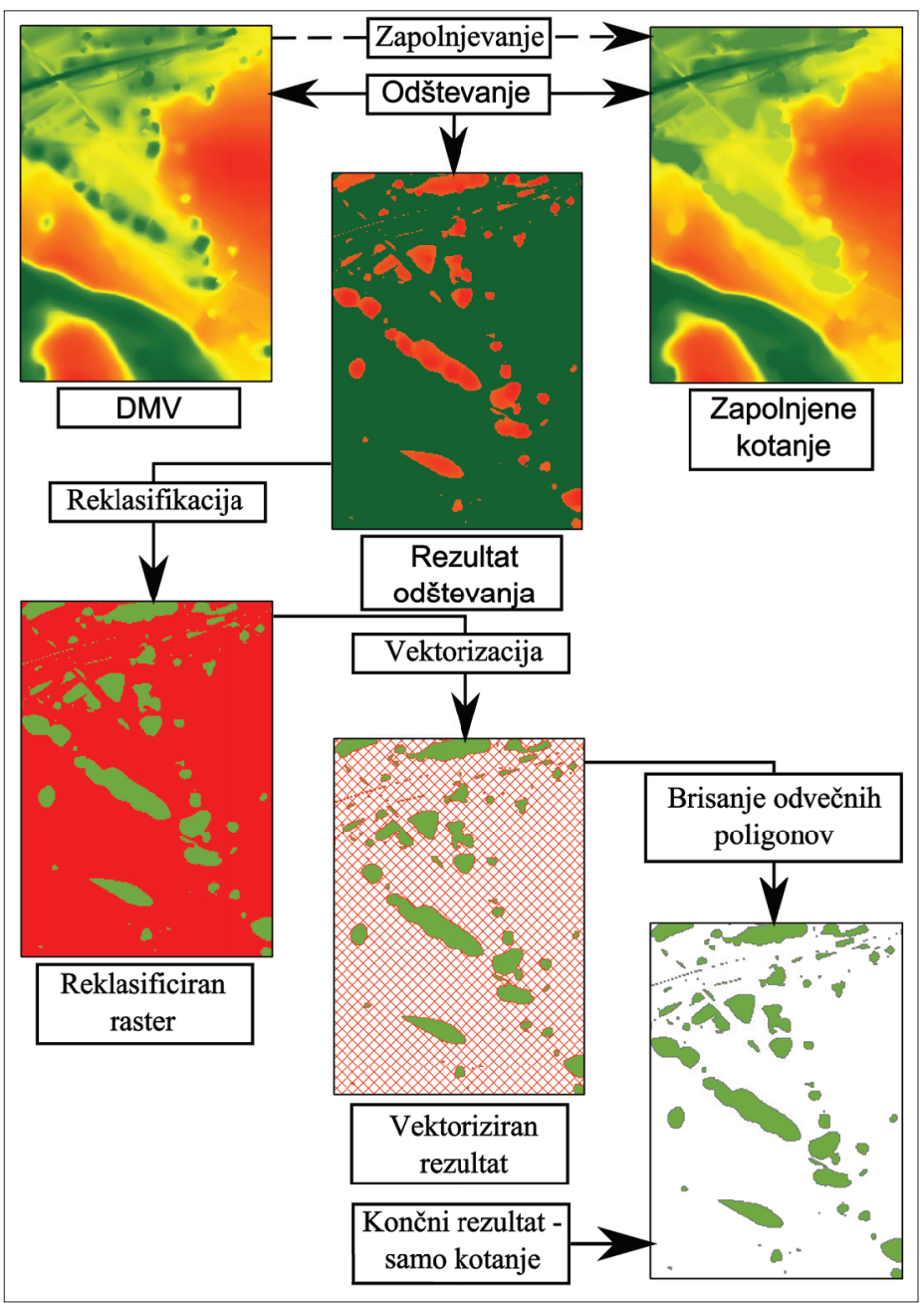


Skript omogoča zaznavanje kotanj na več nivojih, oziroma zaznavanje kompleksnih kotanj, ki vsebujejo manjše kotanje. To je omogočeno prek iterativnega zapolnjevanja kotanj vhodnega DMV z uporabo različnih vrednosti parametra 'Z-limit', s katerim omejujemo globino zapolnjevanja. $V$ vsaki ponovitvi zapolnjevanja uporabimo drugo vrednost parametra. Vrednosti parametra se generirajo kot seznam celih ali decimalnih števil glede na nastavitve uporabnika. Vhodni parametri skripta za ustvarjanje seznama vrednosti parametra 'Z-limit' so:

- začetna vrednost parametra 'Z limit';

- končna vrednost parametra ' $Z$ limit';

- interval vrednosti $v$ seznamu.

Z naštetimi vhodnimi parametri uporabnik nadzoruje število ponovitev zapolnjevanja, natančnost zaznavanja kotanj in s tem čas, ki ga skript potrebuje za izvajanje.

$\mathrm{Za}$ analizo smo uporabili začetni Z-limit 1 , končni Z-limit 10 in interval 0,5 , torej seznam števil $[0,5 ; 1 ; 1,5 ; 2 ; 2,5 ; 3 ; 3,5 ; 4 ; 4,5 ; 5 ; 5,5 ; 6 ; 6,5 ; 7 ; 7,5 ; 8 ; 8,5 ; 9 ; 9,5 ; 10]$. To pomeni, da so se kotanje zapolnjevale dvajsetkrat, začenši z vrednostjo parametra ' $Z$ limit' 0,5 do globine $10 \mathrm{~m}$ v korakih po $0,5 \mathrm{~m}$. Vrednosti parametrov smo določili na podlagi namena raziskave, to je zaznavanja brezstropih jam. Ker se te pojavljajo kot plitvejše kotanje in uleknine, smo globino zapolnjevanja omejili na $10 \mathrm{~m}$. Za vrednost parametra

Slika 3: Primer združenih slojev

Figure 3: Merged layers

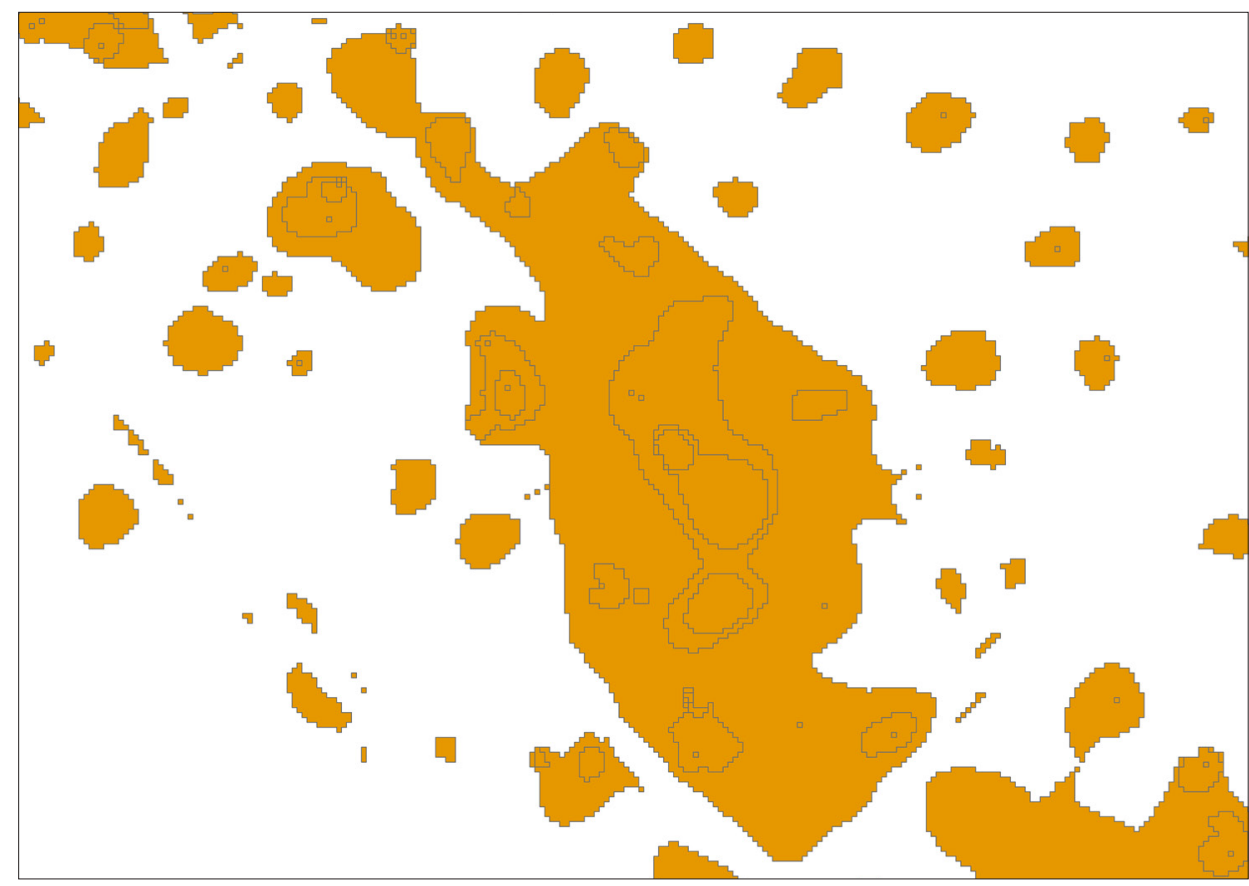


‘interval vrednosti’ v seznamu smo uporabili najmanjšo vrednost, ki jo zaradi omejitev ustvarjanja seznama števil s programskim jezikom Python 2.7.2 skript dovoljuje. Začetna vrednost parametra 'Z limit' mora biti vedno večja od 0 . V nasprotnem primeru bi orodje/ program razumel, da želi uporabnik zapolniti kotanje, ki imajo globino manjšo ali enako $0 \mathrm{~m}$, kar nima smisla.

Kotanje se osamijo z odštevanjem vhodnega DMV od DMV z zapolnjenimi kotanjami. Rezultate predstavljajo rastrski sloji, katerih vrednosti celic odražajo globino kotanje na mestu pripadajoče celice. Celice $\mathrm{z}$ vrednostjo 0 predstavljajo območja, kjer ni razlike med obema DMV, oziroma kjer kotanj ni. V naslednjem koraku skript spremeni vrednosti celic, ki predstavljajo površje kotanj v 1, vrednosti ostalih celic ostanejo 0 . Rezultate reklasifikacije nato vektoriziramo v sloje s poligoni kotanj in ostalih površin. Do tega koraka sloje za posamezne nivoje kotanj (parametre ' $Z$ limit') obdelujemo ločeno. V nadaljevanju vse sloje združimo v enega, pri čemer odstranimo dvojnike kotanj, prepoznanih na različnih nivojih. Slika 3 prikazuje pravilno združene poligone kotanj (oranžna barva) v kompleksnem objektu s kotanjami na štirih nivojih.

\subsection{Klasifikacija pokritosti tal in NDVI}

Za klasifikacijo pokritosti tal smo uporabili prilagojen postopek, ki vključuje prvine objektne in pikselske klasifikacije. Segmentacija in pikselska klasifikacija satelitskega posnetka je bila izvedena v programu Idrisi Selva 17.0, poklasifikacija pa v programu ArcMap 10.1, s katerim smo izračunali tudi NDVI.

$\mathrm{V}$ postopku segmentacije smo vrednost praga, ki določa spektralno podobnost segmentov, nastavili na 30, kar je zagotovilo ustrezno segmentacijo. Nižji prag je povzročil prekomerno, višji pa prešibko segmentacijo posnetka (slika 4).

Slika 4: Primeri segmentacije z različnimi pragovi podobnosti Figure 4: Image segmentation using different similarity thresholds

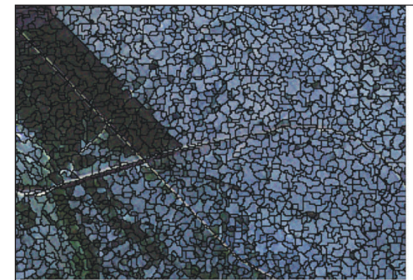

Prekomerna segmentacija (prag podobnosti $=10$ )

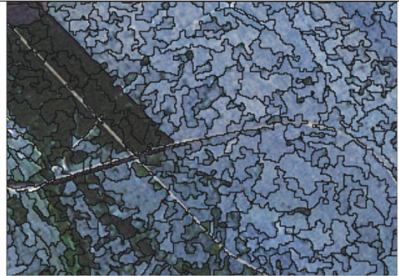

Uporabljena segmentacija (prag podobnosti $=30$ )

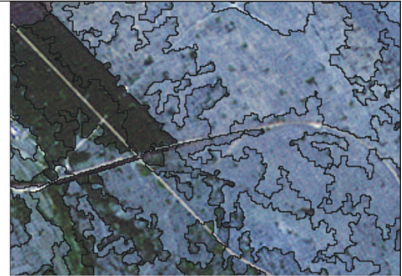

Prešibka segmentacija ( $p$ rag podobnosti $=70$ )

Vir/Source: RapidEye, satelitski posnetek 18. 8. 2012, 2012

Meje segmentov določimo glede na podobnost celic vhodnega posnetka, same segmente pa uporabimo kot učne vzorce za določitev in izdelavo spektralnih podpisov razredov posameznih tipov pokritosti z orodjem SEGTRAIN (IDRISI Selva Help System, 2012). Izdelali smo spektralne podpise za pet tipov pokritosti: pozidano, gozd, travnik, 
požgano in oblak. Satelitski posnetek smo klasificirali z metodo največje verjetnosti. V fazi poklasifikacije smo s filtrom večine iz klasificirane slike odstranili šum, zgladili robove razredov in odstranili majhne izolirane regije celic.

Za območja, klasificirana kot gozd, travnik in požgano, smo izračunali NDVI. To je eden najbolj razširjenih indeksov za opazovanje vegetacije. Izračunamo ga kot razmerje med razliko infrardečega $(I R)$ in vidnega rdečega $(R)$ kanala ter njuno vsoto (enačba 1 ). Rezultat zavzame vrednosti med -1 in 1 , pri čemer višje vrednosti predstavljajo bujnejšo vegetacijo (Oštir, 2006). Enačba 1:

$$
\mathrm{NDVI}=\frac{\mathrm{IR}-\mathrm{R}}{\mathrm{IR}+\mathrm{R}}
$$

Posamezne slike NDVI smo s postavitvijo praga razvrstili v dva razreda tako, da območja bujnejše vegetacije čim bolje odražajo možne povezave z lokacijami kotanj ali alohtonih sedimentov oziroma brezstropih jam. Preglednica 1 prikazuje vrednosti NDVI, pri katerih je bil postavljen prag za posamezen tip pokritosti.

Preglednica 1: Uporabljeni pragovi za klasifikacijo NDVI

Table 1: Thresholds for NDVI classification

\begin{tabular}{|l|c|}
\hline Tip pokritosti & Vrednost praga \\
\hline Travnik & 0,25 \\
\hline Gozd & 0,47 \\
\hline Požgano & 0,049 \\
\hline
\end{tabular}

$\mathrm{Na}$ prag NDVI vplivajo poleg prisotnosti alohtonih sedimentov in posledično ugodnejših razmer za uspevanje rastlinstva tudi drugi dejavniki, kot so nadmorska višina, geološka podlaga in tip gozda. Kljub preizkušanju različnih vrednosti pragov nismo dosegli konsistentnega prikaza območij bujnejšse vegetacije znotraj posameznih tipov. $\mathrm{Ob}$ postavitvi praga pri nižjih vrednostih smo npr. dobro zajeli območja bujnejšega gozda na nižjih nadmorskih višinah, medtem ko so bila ta območja na višjih nadmorskih višinah preobsežna in niso izkazovala povezave s kotanjami ali brezstropimi jamami. Pri postavitvi praga na višjih vrednostih se je zgodilo ravno obratno.

Zaradi opisanega obnašanja slik NDVI teh podatkov nismo uporabili za določanje brezstropih jam. Uporabili smo zgolj masko pozidanih površin, s katero smo iz rezultata zaznavanja kotanj (poglavje 3.1.) odstranili kotanje, ki so antropogeno preoblikovane ali posledica človekovih posegov.

\subsection{Določanje brezstropih jam}

Postopek določanja brezstropih jam (slika 5) pomeni določitev tistih kotanj iz nabora kotanj, zaznanih na podlagi obdelave DMV, ki ustrezajo morfografskim in morfometričnim 
kriterijem brezstropih jam. Celoten postopek je popolnoma avtomatiziran prek skripta, napisanega v programskem jeziku Python 2.7.2 za program ArcMap 10.1, z izjemo prvega koraka, $v$ katerem izbrišemo kotanje, ki so posledica človekovega delovanja.

Skript za analizo povezovanja kotanj v nize zahteva od uporabnika pet številskih parametrov, s katerimi definiramo prostorske odnose in morfometrične lastnosti, ki kotanjo opredelijo kot brezstropo jamo. Prva dva parametra se nanašata na površino poligonov kotanj. Z njima omejimo najmanjšo in največjo površino kotanj, saj so zelo majhne kotanje (1-4 rastrske celice) lahko zgolj napake v DMV, po drugi strani pa v analizo ne želimo vključiti zelo velikih kotanj, saj se brezstrope jame v reliefu ne odražajo kot take. Parameter 'podolgovatost' določa kotanje, za katere v nadaljevanju analiziramo prostorske odnose z ostalimi kotanjami. Kotanje, ki imajo razmerje med daljšo in krajšo osjo večje ali enako vrednosti parametra 'podolgovatost', v obdelavi obravnavamo kot brezstrope jame, oziroma kot izhodišča za iskanje nizov kotanj. Ker se brezstrope jame v površju odražajo kot podolgovate kotanje, mora biti podolgovatost vedno večja od 1 , sicer so kot brezstrope jame vedno prepoznane vse kotanje. S parametroma 'kot iskanja' in 'razdalja iskanja' določamo velikost izbiralnih poligonov (poligonov, ki označujejo brezstrope jame) ter oddaljenost središč teh poligonov od roba kotanje.

Slika 5: Pojmovni model zaznavanja brezstropih jam

Figure 5: Conceptual model of unroofed cave recognition

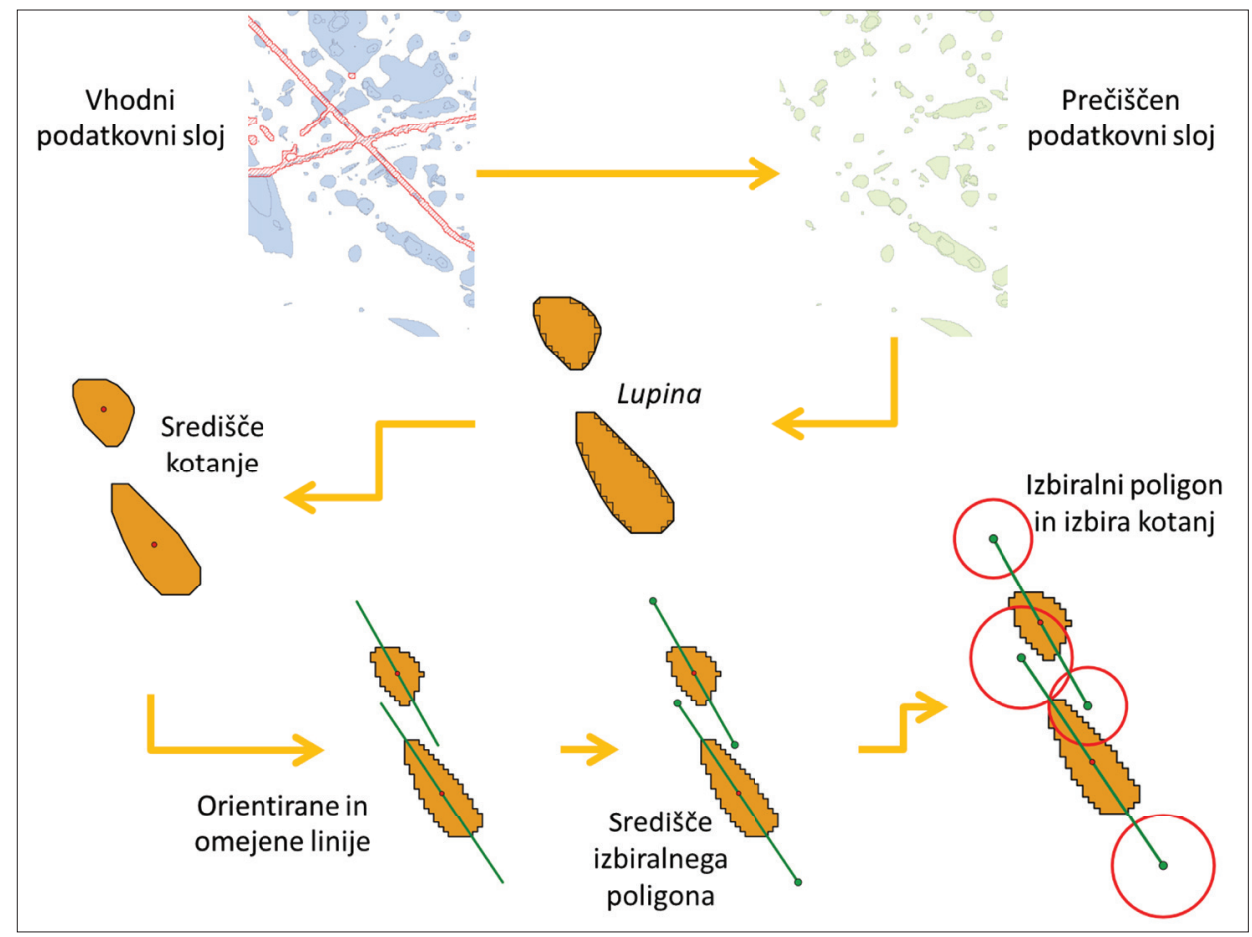


Iz nabora kotanj smo najprej odstranili kotanje, ki so posledica človekovih posegov ali antropogeno preoblikovane. To smo dosegli z odstranitvijo kotanj, ki se prekrivajo z masko pozidanih oziroma preoblikovanih površin, izdelano s klasifikacijo satelitskega posnetka. Skript nadalje odstrani kotanje, ki po velikostnem kriteriju ne ustrezajo morfometričnim lastnostim brezstropih jam (imajo premajhno ali preveliko površino).

Poligonom kotanj prečiščenega podatkovnega sloja z orodjem 'izbočena lupina' (angl. Convex Hull) izdelamo najmanjše oklepajoče geometrije (angl. Minimum bounding geometry). Orodje je najlažji način izračuna orientacije (azimuta) ter dolžin krajše in daljše osi poligonov, ki jih v nadaljevanju uporabimo kot parametre za izračun podolgovatosti. Sloj poligonov kotanj nato pretvorimo v točkovni sloj središč kotanj za natančen izračun njihovih koordinat. Z orodjem 'usmerjena razdalja v linijo' (angl. Bearing distance to line) vsakemu poligonu določimo dva vektorja, ki s krajiščema določata lokaciji središč izbiralnih poligonov. Orientaciji vektorjev sta enaki azimutu in nasprotnemu azimutu (razlika $180^{\circ}$ ) daljše osi pripadajočega poligona. Dolžina vektorjev se izračuna po enačbi 2:

$$
\mathrm{D}=\frac{\mathrm{D}_{\mathrm{do}}}{2}+\mathrm{D}_{\mathrm{du}}
$$

kjer je $D$ dolžina vektorja, $D_{d o}$ dolžina daljše osi poligona kotanje, $D_{d u}$ pa razdalja iskanja, ki jo določi uporabnik. Vektorja poligona nato združimo v en objekt, krajišči pa pretvorimo $\mathrm{v}$ točkovni sloj središč izbiralnih poligonov. Izbiralni poligoni so izdelani z razširitvijo (angl. buffer) krajišč vektorjev. Polmer bufferja $(p)$ je funkcija dolžine vektorja $(D)$ in tangensa polovice kota iskanja $(\alpha)$, kot prikazuje enačba 3:

$$
\mathrm{P}=\mathrm{d} *\left(\tan \frac{\alpha}{2} * \frac{\Pi}{180}\right)
$$

Opisani postopek izvedemo za vse poligone kotanj, zadnji korak oziroma izbiro kotanj v nizu pa samo za poligone, ki ustrezajo kriteriju podolgovatosti. Če je razmerje med dolžino daljše in krajše osi poligona večje ali enako vrednosti parametra 'podolgovatost' kotanje, za poligon izvedemo izbiro na principu preseka oziroma, če izbiralni poligon podolgovate kotanje seka ali se dotika katere koli kotanje, potem to kotanjo izberemo in izvozimo v podatkovni sloj z rezultati, ki vsebujejo zaznane brezstrope jame. V ta sloj izvozimo tudi vse podolgovate kotanje.

Za določanje brezstropih jam iz nabora kotanj smo uporabili naslednje parametre: najmanjša površina kotanje $100 \mathrm{~m}^{2}$, največja površina kotanje $50.000 \mathrm{~m}^{2}$, podolgovatost kotanje 1,5 , kot iskanja $45^{\circ}$ in razdalja iskanja $50 \mathrm{~m}$.

\section{REZULTATI}

Z metodo zaznavanja kraških kotanj smo na proučevanem območju zaznali 2969 objektov s skupno površino $5,6441 \mathrm{~km}^{2}$, kar predstavlja $10,72 \%$ površine obravnavanega območja. Pri brisanju kotanj, ki so posledica človekovega delovanja oziroma so antropo- 
geno preoblikovane, smo izločili 688 kotanj, skript pa je v prvem koraku izbrisal še 974 kotanj s površino, manjšo od $100 \mathrm{~m}^{2}$ in večjo od $50.000 \mathrm{~m}^{2}$. Pri končni analizi smo tako upoštevali 1307 kraških kotanj oziroma 44,02 \% vseh zaznanih kotanj.

Kot brezstrope jame oziroma dele brezstropih jam smo prepoznali 593 poligonov kotanj ali 45,37 \% kotanj, ki smo jih upoštevali v obdelavi. Vse skupaj imajo površino 2,03 $\mathrm{km}^{2}$ in predstavljajo 3,86 \% površine obravnavanega območja. Povprečna površina kotanje, ki predstavlja del brezstrope jame, je $3426 \mathrm{~m}^{2}$, mediana površin pa $1325 \mathrm{~m}^{2}$.

Dna kotanj brezstropih jam so na nadmorskih višinah med $301 \mathrm{~m}$ in $860 \mathrm{~m}$ n.v. (povprečje 457,1 m n.v.), najnižje celice oboda pa na nadmorskih višinah med $302 \mathrm{~m}$ in $862 \mathrm{~m}$ n.v. (povprečje 459,1 m n.v.). Prepoznane brezstrope jame so globoke do 9,6 m, povprečna globina je $2,0 \mathrm{~m}$. Najmanjši obseg kotanje je $50 \mathrm{~m}$, največji $1950 \mathrm{~m}$, povprečni pa je 251,3 m. Površina najmanjše prepoznane kotanje brezstrope jame je $125 \mathrm{~m}^{2}$, največja ima površino $43.800 \mathrm{~m}^{2}$. Po razmerju med osema ima najbolj kompaktna prepoznana kotanja dolgo os 1,1-krat daljšo od kratke, najbolj podolgovata pa 6,1-krat. Povprečna podolgovatost kotanje glede na razmerje je 1,87 .

Pomembna lastnost prepoznanih brezstropih jam je orientacija (slika 6). Največ jih je orientiranih proti vzhod-severovzhodu (113) oziroma zahod-jugozahodu. Kotanje $\mathrm{s}$ to orientacijo, skupaj s kotanjami, orientiranimi proti severovzhodu (82) in severseverovzhodu (89), predstavljajo $48 \%$ vseh kotanj. Enak odstotek kotanj je orientiran pravokotno na te smeri (VJV 109, JV 94, JJV 80). Ta smer nizov in kotanj, orientiranih proti VSV oziroma ZJZ, seka smer dinarske slemenitve pod pravim kotom. Ta pojav je posebej izrazit $v$ severnem delu proučevanega območja ter sovpada s hidravličnim gradientom. Proti južnemu delu območja orientacije kotanj in nizov vse bolj sledijo smeri

Slika 6: Orientacije kotanj, prepoznanih kot brezstrope jame

Figure 6: Orientations of depressions, recognized as unroofed caves

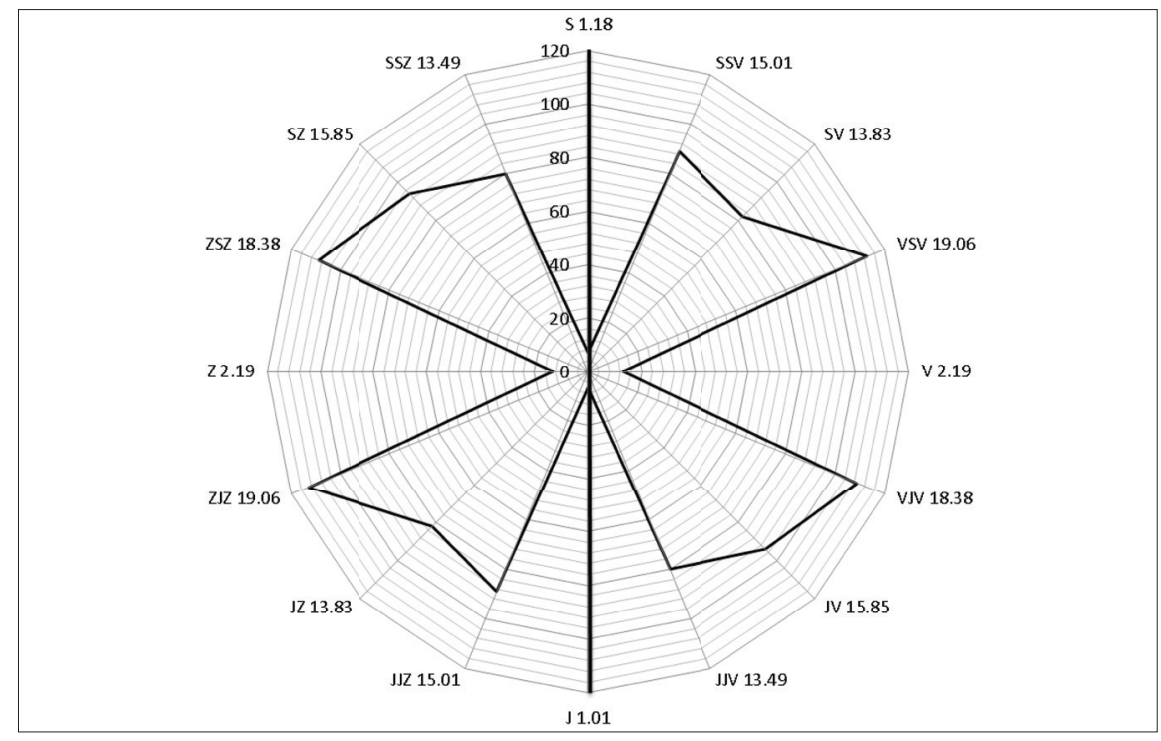


dinarske slemenitve, saj so lokacije zgostitev kotanj bolj omejene z vmesnimi grebeni in slemeni razgibanega reliefa.

Rezultate kabinetnega dela smo preverili na terenu. Pri terenskem delu smo se osredotočili na večje zgostitve kotanj, ki smo jih prepoznali kot brezstrope jame, ter v njih iskali avtohtone in alohtone sedimente, ki dokazujejo, da so res speleogenetskega nastanka (slika 7). V veliki večini pregledanih kotanj smo našli kose sige v dneh, pobočjih in v suhih zidovih. V manjšem delu kotanj smo našli tudi alogene sedimente. Slika 7 prikazuje kotanje, ki smo jih prepoznali kot brezstrope jame, ter lokacije, kjer smo našli sigo.

S terenskim delom smo potrdili primernost razvite metode za iskanje brezstropih jam. Ker skript kot brezstrope jame obravnava vse podolgovate kotanje, smo kot brezstrope jame prepoznali tudi nekatere kotanje, ki to očitno niso. Pri večini gre za nekraške kotanje večjih dimenzij na luskah fliša.

Slika 7: Zaznane brezstrope jame na proučevanem območju Figure 7: Study area and recognized unroofed caves

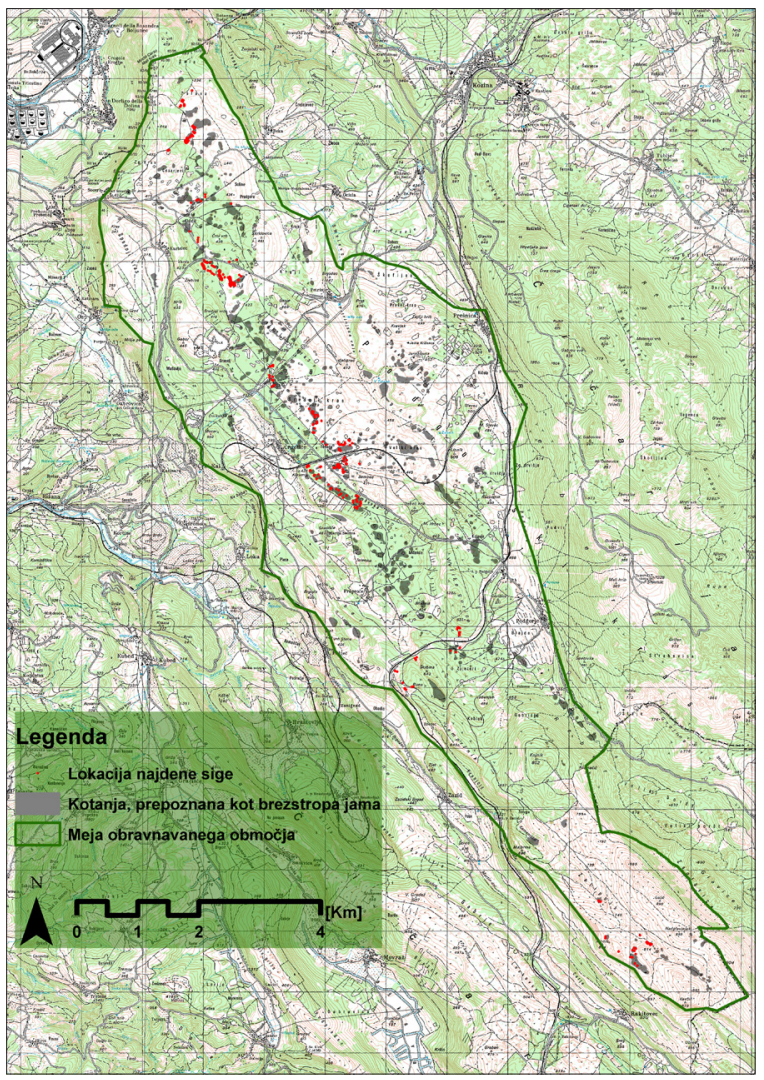

Vir/Source: GURS, DTK 25, 1999 


\section{SKLEP}

Iskanja kraških kotanj in brezstropih jam smo se lotili na dva načina, s katerima smo želeli pripraviti podatke za končno obdelavo oziroma prepoznavanje izbranih pojavov. Vsak način temelji na predpostavki, da se brezstrope jame razlikujejo od ostalega površja in jih je po njihovih lastnostih mogoče zaznati z uporabo tehnologije GIS. Prva predpostavka je, da se lahko brezstrope jame v kraškem površju odražajo kot kotanje, druga pa, da imajo brezstrope jame dovolj specifične rastiščne pogoje za bujnejšo vegetacijo. Izhajajoč iz tega smo za zaznavanje kotanj uporabili DMV 5 in večspektralni satelitski posnetek RapidEye. Z obdelavo DMV smo zaznali 2969 kotanj. Rezultate smo primerjali $\mathrm{z}$ metodo, ki jo je v diplomskem delu razvil Obu (2011) ter ugotovili, da se ne razlikujejo. S tem smo pristop potrdili kot ustrezen.

Rezultati, pridobljeni s klasifikacijo satelitskega posnetka in izračuni NDVI, z izjemo maske pozidanih površin, niso bili dovolj natančni za uporabo v nadaljnji obdelavi. Nenatančnost razdelitve prikazov NDVI na brezstrope jame in ostalo površje se odraža v slikovnih pikah, ki so bile razvrščene kot brezstrope jame, kljub temu da to očitno niso. Gre za slikovne pike, ki na vhodnih slikah predstavljajo gozd ali travnik, na njihov spektralni odboj in posledično razvrstitev pa vplivajo tudi drugi dejavniki in ne samo dejavnik boljših rastiščnih pogojev v brezstropi jami. Tako se ob postavitvi praga, ki na nižjih nadmorskih višinah dobro zajame potencialne lokacije alohtonih sedimentov, na višjih nadmorskih višinah uvrstijo širša območja bujnejše vegetacije. Vzrok za to pripisujemo večji količini padavin in nekoliko nižjim temperaturam na višjih nadmorskih višinah ter posledično bujnejši vegetaciji v času nastanka satelitskega posnetka. Na rezultat vplivajo tudi prisotnost nekarbonatne geološke podlage, ki bolje zadržuje vodo od okolice, ter prisotnost različnih tipov gozda. V nadaljnjih raziskavah se bomo posvetili natančnejši klasifikaciji na več razredov. To bi verjetno pripomoglo k izboljšanju rezultatov in posledično uspešni zaznavi brezstropih jam z opisano metodo, saj le-ti že zdaj nakazujejo možnost aplikacije na manjših in manj heterogenih območjih, kot je obravnavano območje.

$\mathrm{Z}$ zadnjim metodološkim pristopom smo iz nabora kotanj kot brezstrope jame prepoznali 593 kotanj. Metoda je omejena na prepoznavanje brezstropih jam, ki so deloma epifreatično preoblikovane, oziroma vsebujejo vsaj eno podolgovato kotanjo. Rezultate smo preverili na terenu in potrdili pristop kot primeren za odkrivanje brezstropih jam, vendar izpostavljamo pomembnost terenskega pregleda, saj z opisano metodo kot brezstrope jame opredelimo tudi nekatere kotanje, ki to niso. Poleg tega smo na terenu naleteli na brezstrope jame, ki niso izoblikovane kot kotanje in jih skripta nista zaznala oziroma prepoznala.

Skript, ki smo ga napisali in uporabili v zadnjem delu analize, preverja sosedske odnose med poligoni kotanj. Z vidika GIS in orodij, ki jih le-ti ponujajo, predstavlja skript inovativno rabo in kombinacijo osnovnih orodij za analizo vektorskih podatkov. Kot najbolj dodelan element analize sosedstva velja izpostaviti usmerjeno izbiranje poligonov kotanj v okolici izhodiščnih poligonov. Izbiranje izhaja iz orientacije izhodiščnega poligona. Velikost območja izbiranja (izbiralnega poligona) se prilagaja velikosti izhodiščne kotanje, ki ji pripada, ter zahtevam uporabnika. Uporabnik na velikost območja izbi- 
ranja vpliva prek kota iskanja in razdalje iskanja. Skript ponuja veliko možnosti analize različnih prostorskih pojavov ter odvisnosti med njimi. Zato bomo nadaljevali z razvojem skripta, ki bo s prvo nadgradnjo omogočal grupiranje poligonov glede na to, kateri poligon jih je izbral. Z drugimi besedami: kotanja ali kotanje, ki jih bo izbral določen izbiralni poligon, bodo v postopku dobile enak številski atribut. Skript želimo dodelati do te mere, da bo znal prepoznati poligone, $v$ našem primeru kotanje, ki pripadajo isti brezstropi jami. Tako bodo lahko v isto skupino vključeni poligoni, ki niso neposredno povezani med seboj, temveč se povezujejo prek drugih poligonov. Takšna rešitev omogoča usmerjeno analizo skupin na zelo velikem naboru vektorskih prostorskih podatkov.

\section{Zahvala}

Zahvaljujemo se Centru odličnosti Vesolje-SI, ki je omogočil obdelavo satelitskega posnetka RapidEye in s tem izvedbo raziskave.

\section{Viri in literatura}

Brus, N., 2012. Jame brez stropa na izbranih primerih s Krasa in Vremščice. Zaključno delo. Koper, Fakulteta za humanistične študije, Oddelek za geografijo, 58 str.

Corine Land Cover. 2006. Ljubljana, Agencija Republike Slovenije za okolje. URL: http://gis.arso.gov.si/wfs_web/faces/WFSLayersList.jspx;jsessionid=ac1300a33 0ddd9ca7383a5ca48fc99bfddaf96b5d11d.e34Sbh8Ob38NaO0Lb38Qe0 (Citirano 17. 6. 2014).

Dawkins, B. W., 1874: Cave hunting, researches on the evidence of caves respecting the early inhabitants of Europe. London, Macmillan \& Co, 492 str.

Digitalna Osnovna geološka karta (OGK1) 1 : 100.000. 2003. List Trst. Ljubljana, Geološki zavod Slovenije.

DMV 5. 2007. Ljubljana, Geodetska uprava Republike Slovenije.

Doctor, D. H., Young, J. A., 2013. An evaluation of automated GIS tools for delineating karst sinkholes and closed depressions from 1-meter lidar-derived digital elevation data. 13th sinkhole conference, NCKRI symposium 2, str. 449-458. URL: http:// scholarcommons.usf.edu/cgi/viewcontent.cgi?article $=1156 \&$ context $=$ sinkhole_2013 (Citirano 23. 6. 2014).

Državna topografska karta Republike Slovenije 1 : 25.000 (DTK 25). Listi Buzet, Dekani, Kozina, Obrov, Oprtalj, Rašpor. 1999. Ljubljana, Geodetska uprava Republike Slovenije.

Fuyuan, L., Yunan, D., 2013. An automated method to extract typical karst landform entities from contour lines on topographic maps. Geomorphometry, 2013, str. 71-74. URL: http://geomorphometry.org/system/files/LiangDu2013geomorphometry.pdf (Citirano 23. 6. 2014).

Gabrovšek, F., Stepišnik, U., 2011. On the formation of collapse dolines: a modelling perspective. Geomorphology, 134, 1-2, str. 23-31. DOI: 10.1016/j.geomorph.2011.06.007

Gams, I., 2004. Kras v Sloveniji v prostoru in času. 2. pregledana izdaja. Ljubljana, Založba ZRC, 515 str. 
Geršl, M., Stepišnik, U., Šušteršič, S., 1999. Brezstropa jama pri bunkerju (Laški ravnik). Acta carsologica, 28, 2, str. 77-90. URL: http://carsologica.zrc-sazu.si/downloads/282/bunker.pdf (Citirano 17. 6. 2014).

Guimarães, R. F., de Carvalho Júnior, O. A., de Souza Martins, E., Ferreira de Carvalho, A. P., Trancoso Gomes, R. A., 2005. Detection of karst depression by aster image in the Bambui Group, Brazil. V: Ehlers, M., Michel, U. (ur.). Remote sensing for environmental monitoring, GIS applications, and geology V. SPIE Proceedings, 5983, 12 str. URL: http://spie.org/Publications/Proceedings/Paper/10.1117/12.627741 (Citirano 23. 6. 2014).

Digitalni model višin 5 x 5 m (GURS, 2014). 2014. Geodetska uprava Republike Slovenije. URL: http://www.e-prostor.gov.si/zbirke_prostorskih_podatkov/topografski_in kartografski_podatki/digitalni_model_visin/digitalni_model_visin_5_x_5_m_dmv_ $\overline{5}$ (Citirano 23. 6. 2014).

IDRISI Selva help system. 2012. Segtrain. Clark Labs (Citirano 24. 6. 2014).

Kaligarič, M., 1997. Rastlinstvo Primorskega krasa in Slovenske Istre: travniki in pašniki. Koper, Zgodovinsko društvo za južno Primorsko, Znanstveno-raziskovalno središče Republike Slovenije, 111 str.

Kanjir, U., 2009. Objektna klasifikacija rabe tal iz podatkov daljinskega zaznavanja. Diplomsko delo. Ljubljana, Fakulteta za gradbeništvo in geodezijo, Oddelek za geodezijo, 80 str. URL: http://drugg.fgg.uni-lj.si/60/1/GEU_0808_Kanjir.pdf (Citirano 23. 6. 2014).

Knez, M., Slabe, T., 1999. Unroofed caves and recognising them in karst relief (discoveries during motorway construction at Kozina, South Slovenia). Acta carsologica, 28, 2, str. 103-112. URL: http://carsologica.zrc-sazu.si/downloads/282/kozina.pdf(Citirano 17. 6. 2014).

Knez, M., Slabe, T., 2007. Jame brez stropa so pomembna sled razvoja krasa. V: Knez, M., Slabe, T. (ur.). Kraški pojavi, razkriti med gradnjo slovenskih avtocest. Ljubljana, Založba ZRC, str. 135-142.

Knez, M., Šebela, S., 1994. Novo odkriti kraški pojavi na trasi avtomobilske ceste pri Divači. Naše jame, 36, str. 102.

Kraus, F., 1894. Höhlenkunde. Wege und Zweck der Erforschung unterirdischer Räume. Wien, C. Gerold's Sohn, 308 str.

Krevs, M., 1992. Iskanje lokalnih reliefnih ekstremov na DMR. Geografski vestnik, 64, str. 205-218. URL: http://www.dlib.si/stream/URN:NBN:SI:DOC-N03KBQYL/ bb147c8b-2b76-448e-8f89-0425bfcf9d69/PDF (Citirano 17. 6. 2014).

Mais, K., 1999. Roofless caves, a polygenetic status of cave development with special references to cave regions in the Eastern Calcareous Alps in Salzburg and Central Alps, Austria. Acta carsologica, 28, 2, str. 145-158.

Mihevc, A., 1996. Brezstropa jama pri Povirju. Naše jame, 38, str. 65-75

Mihevc, A., 2001. Speleogeneza Divaškega krasa. Ljubljana, Založba ZRC, 180 str.

Mihevc, A., 2007. Nove interpretacije fluvialnih sedimentov na Krasu. Dela, 28, str. 1528. DOI: http://dx.doi.org/10.4312/dela.28.2.15-28 
Obu, J., 2011. Prepoznavanje kraških kotanj na podlagi digitalnega modela višin. Diplomsko delo. Ljubljana, Filozofska fakulteta, Oddelek za geografijo, 101 str.

Obu, J., Podobnikar, T., 2008. Algoritem za prepoznavanje kraških kotanj na podlagi digitalnega modela reliefa. Geodetski vestnik, 57, 2, str. 260-270. URL: http://geodetskivestnik.com/cms/images/57/2/gv57-2_obu.pdf (Citirano 17. 6. 2014).

Oštir, K., 2006. Daljinsko zaznavanje. Ljubljana, Založba ZRC, 250 str.

Pedološka karta. 2008. 1 : 25.000. Ljubljana, Ministrstvo za kmetijstvo, gozdarstvo in prehrano. URL: http://rkg.gov.si/GERK/documents/PedoloskaKarta.zip (Citirano 17. 6. 2014).

Podobnikar, T., 2008. Nadgradnja modela reliefa Slovenije z visokokakovostnimi podatki. Geodetski vestnik, 52, 4, str. 834-853. URL: http:/www.geodetski-vestnik. com/52/4/gv52-4_834-853.pdf (Citirano 17. 6. 2014).

Podobnikar, T., Možina, P., 2008. Analiza oblik površja z uporabo lokalnega okna. V: Perko, D. (ur.). Geografski informacijski sistemi v Sloveniji 2007-2008. Ljubljana, Založba ZRC, str. 29-39.

Rahimi, M., Alexander, E. C. Jr., 2013. Locating sinkholes in lidar coverage of a glaciofluvial karst, Winona county, Mn. 13th sinkhole conference, NCKRI symposium 2, str. 469-480. URL: http://scholarcommons.usf.edu/cgi/viewcontent.cgi?article=1158 \&context $=$ sinkhole 2013 (Citirano 23. 6. 2014).

RapidEye. 2012. Satelitski posnetek 18. 8. 2012. BlackBridge.

RapidEye Satellite Sensor. 2013. URL: http://www.satimagingcorp.com/satellite-sensors/other-satellite-sensors/rapideye (Citirano 23. 6. 2014).

Stepišnik, U., 2006. Ilovnate zapolnitve v udornicah v zaledju izvirov Ljubljanice. Dela, 26, str. 75-89. DOI: 10.4312/dela.26.6.75-89

Stepišnik, U., 2010. Udornice v Sloveniji (Zbirka E-GeograFF, 1). Ljubljana, Znanstvena založba Filozofske fakultete, 118 str. URL: http://geo.ff.uni-lj.si/sites/default/files/eGeograFF-1-stepisnik.pdf (Citirano 17. 6. 2014).

Stepišnik, U., 2011. Sediments in collapse dolines on the Kras plateau, Slovenia. Acta geographica Slovenica, 51, 2, str. 233-252. DOI: 10.3986/AGS51201

Stepišnik, U., Ferk, M., Kodelja, B., Burger, B., Abramović, M., Peterca, S., 2009. Brezstropa jama v Podbojevem lazu, Rakov Škocjan. Dela, 31, str. 37-53. DOI: 10.4312/ dela.31.3.37-53

Šušteršič, F., 1998. Interaction between a cave system and the lowering karst surface: case study: Laški ravnik. Acta carsologica, 27, 2, str. 115-138. URL: http://carsologica.zrc-sazu.si/downloads/272/interact.pdf (Citirano 17. 6. 2014).

Weichelt, H., Rosso, P., Marx, A., Reigber, S., Douglass, K., Heynen, M., 2014. The RapidEye red edge band white paper. BlackBridge. URL: http://www.google.si/url $? \mathrm{sa}=\mathrm{t} \& \mathrm{rct}=\mathrm{j} \& \mathrm{q}=\& \mathrm{esrc}=\mathrm{s} \&$ source $=$ web $\& \mathrm{~cd}=1 \& \mathrm{ved}=0 \mathrm{CB} 4 \mathrm{QFjAA} \&$ url $=\mathrm{http} \% 3 \mathrm{~A}$ $\% 2 \mathrm{~F} \% 2 \mathrm{Fblackbridge.com} \% 2 \mathrm{Frapideye} \% 2 \mathrm{Fupload} \% 2 \mathrm{FRed}$ Edge_White_Paper. pdf\&ei=ToCUVNqLL-Ws7AabwYCQCw\&usg=AFQjCNGgGYok96qSaN2FTiesS _5jCLW-TQ\&bvm=bv.82001339,d.ZGU (Citirano 23. 6. 2014). 


\section{USE OF DIGITAL ELEVATION MODEL AND RapidEye SATELLITE IMAGE TO LOCATE KARST DEPRESSIONS AND UNROOFED CAVES OF PODGORSKI KRAS}

\section{Summary}

Two types of data were used to detect the unroofed caves. They can be expressed as depressions in karstic landscape. Therefore, we used the digital elevation model with spatial resolution of $5 \mathrm{~m}$ to extract the karst depressions in the first step of the research. The unroofed caves can also contain patches of allogenic sediments that provide better growth conditions for the vegetation. In the second step we used the multispectral satellite imagery (RapidEye) for the NDVI calculation. Finally, the extraction of the unroofed caves was performed by analysing the results of the first two parts.

For the detection of depressions we have developed a script in the Python programming language, which performs all the necessary commands and procedures automatically. The method is based on an iterative filling of the DEM's depressions. By subtraction of the filled and the original DEM the script identified 2,969 depressions.

The search for the unroofed caves which are not reflected in the surface as depressions was performed using the method of pixel classification and NDVI calculation. Classification of the satellite image was performed in the program Idrisi Selva 17.0. Post-classification and NDVI calculations were performed in the program ArcMap 10.1. The satellite image was classified into five types of land cover (forest, meadow, burned, cloud and built or anthropogenically modified). NDVI calculations were performed for each class separately. NDVI images were divided into two classes by setting the threshold value at which the visual interpretation best reflects the location of roofless caves. Although the method detected the location of unroofed caves to some extent correctly, the results were not used in the final analysis due to the lack of precision.

In the last part of the cabinet work, we analysed the data layer of the depressions extracted from DEM. Potential unroofed caves were detected on the basis of the morphometric characteristics and spatial relationships between the depressions. The script that was written for this purpose in the Python programming language, analyses the size and elongation of the depressions, their orientation and spatial relations to the neighbouring depressions. The numerical criteria (parameters) that have to be met for the depression to be recognised as an unroofed cave are specified by user. In our research, depressions with area between $100 \mathrm{~m}^{2}$ and 50,000 $\mathrm{m}^{2}$ and elongation (aspect ratio) of at least 1.5 were used as starting points for spatial relations analysis. The search for the next depression in series was then performed in the direction of the elongated depression's azimuth, $50 \mathrm{~m}$ from the edge of the first depression and at an angle of $45^{\circ}$. Detected depressions were exported to the output layer.

With the described method, 593 depressions were identified as unroofed caves. Results were used as a guide for the fieldwork where we have searched for evidences (autogenous cave sediments and allogeneic sediments or fillers) that recognised depressions are unroofed caves indeed. Flowstone was found in almost all depressions that were identified and a smaller number of depressions contained also allogeneic sediments. 
The applied method of the unroofed caves extraction from the DEM delivers reliable results. Detection method of the considered phenomena from multispectral remote sensing products is, in spite of some inaccurate results, evaluated as a potentially good solution for upgrading results obtained by the DEM processing. The method is suitable for use on small and homogeneous study areas, additionally we must be careful with a large number of factors that can affect the spectral reflectance of vegetation and adjust the parameters of the tools according to those factors.

(Translated by the authors) 